\title{
A Mosque Programme for the Wellbeing of Muslim Families
}

\section{Al-Sharmani, Mulki}

Routledge

2019

Al-Sharmani , M 2019 , A Mosque Programme for the Wellbeing of Muslim Families . in M Tiilikainen , M Al-Sharmani \& S Mustasaari (eds), Wellbeing of Transnational Muslim

Families : Marriage, Law, and Gender . Studies in Migration and Diaspora, Routledge , London , pp. 59-77 . https://doi.org/10.4324/9781315231976-4

http://hdl.handle.net/10138/313319

https://doi.org/10.4324/9781315231976-4

cc_by_nc_nd

publishedVersion

Downloaded from Helda, University of Helsinki institutional repository.

This is an electronic reprint of the original article.

This reprint may differ from the original in pagination and typographic detail.

Please cite the original version. 


\title{
4 A mosque programme for the wellbeing of Muslim families
}

\author{
Mulki Al-Sharmani
}

Somalis say they know religion, but they only know to pray, and go to mosques, they do not know to work on marriages and families.

A mosque imam and a key organizer of the mosque programme for Muslim families.

\section{Introduction}

The quotation above alludes to the concerns of a Helsinki mosque programme regarding Finnish Somalis' religious understandings and family practices and their impact on their wellbeing. This chapter tackles how Muslim religious institutions in Finland understand and play a role in the pursuit of family wellbeing. I focus on the work of one mosque programme, which was established in 2011 and predominantly serves Somali families. I examine the programme's two stated goals: the 'good of Muslim families', and their 'positive integration' into Finnish society. How are these two goals understood, interconnected, and pursued by programme organizers? And how can the concept of wellbeing (White, 2008; 2010; 2016) help us understand the programme's vision and work?

I trace both the local and transnational contexts shaping the work of the mosque programme. As Finland is increasingly becoming multicultural and multi-religious through immigration, family wellbeing becomes ever more intertwined with the issue of integration and empowering membership in the society. Somalis, the largest Muslim black immigrant community in Finland, confront multidimensional challenges such as economic marginalization, educational and employment challenges, limited social mobility, and racism (OSF, 2013). I examine how the goals of the mosque programme are driven by tackling the impact of these challenges on marriage relationships and parent-children relations. Also relevant to the programme is the Finnish state governance of religious communities. Recent scholarship argues that changes in the welfare state after the 1990s have resulted in a new form of governance where third sector associations and civil society partake (with the state) in the work of family welfare and identity-making (Mårtensson, 2014; Martikainen, 
2014). As part of this new governance, new laws and policies have been passed which create more legal and public space for religious institutions from minority communities. I shed light on how the researched programme is enabled by these state policies.

Additionally, I highlight how the vision and language of the mosque programme are also shaped by its being part of a loose network of Islamic institutions and individual religious scholars across Europe. This network works towards promoting modern and harmonious Muslim families who are grounded in Islamic norms while at the same empowered and active members of their respective societies. I examine, in particular, the mosque's discourse on companionate marriage and engaged parenting. I analyse the Islamic arguments and language used in this discourse, reflecting on their gender implications.

\section{Research background}

This chapter is part of a larger study on Muslim marriage norms and practices in Finland. ${ }^{1}$ I conducted the ethnographic research on the selected mosque from 2013 to 2017. I collected data through: participant observation, interviews, life history interviews, informal discussions, and content analysis. ${ }^{2}$ I conducted participant observation of family seminars, usually held once every four to six weeks for six hours each time. I also attended two annual conferences organized in 2015 and 2016.

I conducted a series of individual and group interviews with nine key interlocutors (four men and five women) who were organizing and assisting with programme work. I also interviewed and had informal discussions with programme participants. My access to female participants was better than the male for several reasons. More women than men attended the activities. Also, because women and men sit separately on parallel sides of the room during programme events, I was often in the company of women rather than men. Hence, I conducted group interviews with eight female participants as well as individual lifehistory interviews with three of these participants. I also had many informal discussions with the women. While I did not get to interview individual male participants, I had informal discussions with some of them. All interviews and discussions were conducted in Somali. In addition, I analysed programme pamphlets, seminar PowerPoint presentations, and videotaped lectures.

Two final points regarding research ethics are noteworthy. To ensure that this research does no harm to my interlocutors, I discussed with them the issue of anonymity and confidentiality. It was their decision that while the name of their mosque would not be disclosed, accurate and sufficient information would be provided about the programme to help with their advocacy for its goals. Programme organizers, furthermore, read several drafts of this chapter and approved its accuracy and its adherence to our agreement.

Cognizant of the vexing question of power and knowledge in anthropology and feminism as fields of knowledge, I have also reflected on my own 
positionality as a researcher (Abu-Lughod, 1990). I share with my interlocutors the same religious and Somali diasporic background although as an immigrant I grew up elsewhere. This shared background, on the one hand, facilitated my access and ability to do the research. On the other hand, it made me more aware and reflective of power relations in my research and its potential consequences for my interlocutors. I discussed candidly with my interlocutors a common perception among the Somalis in Finland that they have been over-researched because of their visibility as the largest Muslim black community, yet this research has often been perceived to have benefitted the researchers more than the immigrants themselves. My interlocutors and I agreed that one way to partially redress this issue in this study is that I undertake volunteer work that would directly benefit them. Upon the request of the women, I committed to teaching them English once a week in the mosque, and the class has been open to women and girls from the community at large. This volunteer work since then has become - for me - part of a larger personal/political engagement that goes beyond the scope of this research.

\section{Religious communities in Finland}

The Lutheran Church of Finland is the official church of the country with a long history of close relationship with the state (Sakaranaho, 2013). The Orthodox Church also has similar official status. The largest religious communities belong to the Lutheran Church with $80.6 \%$ of the total population, the latter being approximately 5.5 million (Statistics Finland, 2016). Muslims, whose number is roughly $60,000-65,000$, constitute $1 \%$ of the total population. Muslims in Finland have diverse backgrounds. In addition to some 600 Finnish Tatars who are also the oldest Muslim community, there are Muslim communities from: the Horn of Africa, North Africa and the Middle East, Sub-Saharan Africa, South East Asia, and the Indian subcontinent, as well as Finnish converts. The majority of the Muslim communities are of refugee background. The Somalis comprise the largest Muslim and African community, with a total number of 19,059 in 2016 (Statistics Finland, 2016).

In the 20th century, as Finland was increasingly becoming multi-religious, there was a need to recognize this religious diversity and affirm the equality of all citizens. Therefore, in 1923 the Freedom of Religion Act was introduced. This law affirms the separation of the state and church, cementing the autonomy of the church which had begun in the late 19th century (Kääriäinen, 2011, p.157). The law also safeguards the freedom of citizens to profess and practise religion freely, and to form religious communities. The right to freedom of religion was also enshrined in Finland's 1919 constitution at the time. In 2003, a new Freedom of Religion Act was introduced. This new law introduced the notion of 'positive freedom of religion'. (Kääriäinen, 2011, p.158). It was now the state's responsibility not only to safeguard against religious discrimination but also to create an environment where citizens can 
practise their religion - the latter now being seen as part of 'community tradition' to be nurtured (Kääriäinen, 2011, p.158). The country's new constitution, which was passed in 2000, also affirms the state's double role as protector of religious equality and nourisher of citizens' and communities' religious identities (Kääriäinen, 2011, p.157). Like its predecessor, the new Freedom of Religion Act stipulates that a minimum of 20 individuals can establish a religious community. Religious communities can register with the state either under the Freedom of Religion Act or under the Association Act of 1989. Communities registered under the former have to meet more rigid criteria than those registered under the latter law, but they enjoy more rights such as the legal authority to conclude marriages and the right to religious education (Kääriäinen, 2011, p.158). Registered religious communities are entitled to receive annual financial assistance from the state if they have at least 200 registered members.

In the early 1990s, there were a handful of mosques ${ }^{3}$ in Finland. But by the 2010s the total number had reached 50 as many made use of the new state laws to register as religious communities (Ketola, Martikainen and Salomäki, 2014). In earlier eras, most of these mosques were ethnically divided, whereas nowadays there is a combination of multi-ethnic and ethnically divided mosques. For example, there are three main mosques in Helsinki managed and frequented by Somalis, including the researched mosque. There are also mosques in Helsinki predominantly frequented by South Asians, English speaking Muslims, Finnish converts, and the Shi'a community. Most mosques provide religious and social services such as conducting daily and Friday communal prayers, Ramadan and Eid prayers, weekly religious classes for children and adults, and burial rites. In addition, mosques usually conclude marriages and divorces, ${ }^{4}$ as well as undertake family dispute resolution.

The researched mosque is part of a non-profit Islamic umbrella organization that was first established in 1986. It was the second Islamic organization in the country after the Tatar Islamic organization and mosque, which were established in the first half of the 20th century. The total number of the mosque's registered members is between 1700 and 1800 , with 600 to 800 members paying annual donations. The majority of members are Somalis, but some come from other ethnic backgrounds. The members of the advisory council overseeing the umbrella organization are of diverse ethnic background, but those running mosque activities are predominantly Somalis. The umbrella organization consists of eight associations covering Qur'anic education and recitation, media, children's day care, women, youth, Islamic relief, endowments, and family wellbeing. It is this latter association that manages the researched programme. The mosque is registered according to the 2003 Freedom of Religion Act, while the associations comprising the umbrella organization are registered according to the Association Act of 1989. 


\section{Al-Usra al Muslima: A mosque programme for families}

\section{The 'good of the family' and 'positive integration': seeking wellbeing?}

The mosque programme is well structured with a clear vision and goals. It was established in February 2011 and is called Muslim Families of Finland, or simply al-Usra (the Arabic word for the family). Al-Usra provides mediation and arbitration for family disputes. It also holds regular seminars for families, promoting knowledge and skills that enhance the 'good' of the family. The programme, furthermore, holds lectures for youth, which cover Islamic family law, foundations for good Muslim marriages, Finnish family laws, the place of love in marriage, etc. Since late 2016, the programme has also begun training workshops for parents and newlyweds. These workshops, however, have not been regular. Once a year, the programme also hosts an international conference bringing together Muslim religious scholars and community activists mostly from Europe but on some occasions from North America and Somalia as well. The programme conducts all its activities (with the exception of family dispute resolution work) in Somali and targets Somali Muslim families. But the organizers are planning to extend this work to nonSomali Muslim families, once they have recruited enough volunteers from other ethnic backgrounds.

The programme is organized by five board members (three men and two women). The men are first-generation immigrants who are in their forties, while the women are in their mid-thirties and moved to Finland in their teens. Two of the male board members are also the mosque imams and members of the dispute resolution committee. One of these imams had a previous career in a professional field but was also mentored in Islamic religious sciences first by mosque imams in Somalia and then in Finland. The other imam was also mentored in Somalia and was at the time of the research pursuing a longdistance degree in Islamic religious sciences from a private institution in Europe. The other three board members are: a male member who teaches Islam in public schools and had a previous career in a business-related field, and two female members who work in the fields of health and social work. The three male board members are the ones who normally lecture on Islamic teachings in the seminars and workshops. The female board members, on the other hand, give presentations on health-related issues, invite speakers from different Finnish organizations, and advertise activities.

These board members are assisted by four interlocutors (one man and three women). These helpers are in their late twenties and moved to Finland when they were young children. The male interlocutor is also pursuing a long-distance degree in Islamic religious sciences. The three women also work in the health sector. While the women interlocutors do not have formal expertise in religious knowledge, they are all diligently pursuing religious knowledge from multiple sources (e.g. classes at the mosque, independent studies from books and online lectures, etc.). 
The scholar Sarah White $(2008 ; 2010 ; 2016)$ produced a series of important writings engaging with the concept of wellbeing and developing it as a layered and useful analytical tool in social sciences. Drawing on White's work, I understand wellbeing to be not simply an outcome but rather a holistic process that encompasses material, relational, and ethical dimensions. The material dimension covers resources needed for daily lives such as education, jobs, housing, health, physical safety, places of worship, legal mechanisms of marriage and divorce, etc. The relational dimension has to do with the social relations in which people's lives are embedded in the family, community, or larger society. And the ethical dimension is related to the systems of norms, laws, and values that shape people's decisions, actions, and claims. The three dimensions are organically linked, and the process of seeking and experiencing wellbeing is shaped by the specific temporalities and localities of the people concerned.

This conceptualization of wellbeing, I contend, is a useful tool to understand the al-Usra programme. The organizers often describe their work as having two intertwined goals: the 'good of Muslim families', and their 'positive integration'. That is, the pursuit of both goals, in the programme's vision, is very much akin to the notion of seeking multidimensional wellbeing encompassing its material, relational, and ethical aspects. Realizing both goals, furthermore, necessitates two interconnected pathways: first, programme participants are to acquire good knowledge of Islamic norms on marriage and parenting, knowledge of the distinction between Islamic and Somali cultural norms, knowledge of modern ideas and concepts in psychology and communication so as to acquire the skills needed to have healthy family relationships, and knowledge of laws and norms of the larger society so as to claim and experience empowering membership in the society. Secondly, participants are to apply this knowledge to establish harmonious and cooperative relationships with family members and the larger society.

The attainment of the good of the family, on one level, has to do with fulfilling their material needs such as education, employment, and housing as well as knowledge of relevant policies and institutions for family welfare. On a relational level, it is concerned with reforming participants' relationships with their spouses and children. Additionally, the 'good of the family' includes an ethical dimension which entails acquiring the 'correct' understanding of religious norms on marriage and family relations, reflecting critically on Somali cultural norms that are seen to justify male dominance in marriage and gendered parenting roles, and navigating Islamic family law and Finnish state codes.

Positive integration, according to the programme organizers, is a distinct kind of engaged and empowered membership in the society while maintaining one's Islamic norms and identity. Similar to the first goal, 'positive integration' is also a process that has material, relational, and ethical dimensions. Again, on the material level, it means acquiring knowledge of the policies and services of state and third sector organizations concerned with participants' 
family life such as the health sector, schools, law enforcement, child protection agencies, community centres providing leisure activities, registrar offices recording marriages, etc. On a relational level, it involves interacting with these institutions from a position of knowledge, agency, and cooperation. Ethically, positive integration means navigating successfully the multiple norms and laws that regulate or impact participants' family life.

Programme organizers repeatedly emphasize the intertwining of the good of the family and its positive integration. One cannot happen without the other and vice versa. To provide better care for one's children and become a better spouse and parent, one needs to have the knowledge of state and third sector policies and services that impact family wellbeing. One also needs to reach out to relevant institutions, not as a marginalized immigrant but as a right-bearing and engaged citizen. The connection between the two goals is captured by a female programme organizer in the following quotation, as she explains why she is doing this work:

I was very eager to work in this programme. Muslim families have a lot of problems here, but we Somalis, especially, have a problem. The state provides housing, education, health, and many things. But people do not have knowledge, people keep to themselves. There is fear, we have been living here for many years, but mothers are afraid, they do not use state services, they do not interact with them, they are afraid their children will be taken, they do not join the society. And some people think this is a gaal (non-Muslim) society and so they keep to themselves. And Somali fathers, those who are physically here and those who are not, they are all the same, they are not doing their part. When I listened to the seminar of ... [the co-founder of the programme], I felt this is exactly what we need. Our goal is a Finnish, Somali, Muslim identity, and to build this for the young generation. How can Somali families living here build this identity? This is our goal.

The following ethnographic vignette, furthermore, sheds light on the programme's promotion of multifaceted family wellbeing:

In a family seminar, the mosque imam began the event with Islamic teachings on how to prepare oneself spiritually for the month of Ramadan as the blessed month was approaching. Then another programme organizer, a trained nurse, presented health advice on how participants could take care of their physical wellbeing while fasting (e.g., how women and men could take care of their skin). This was followed by a presentation by an invited medical expert on recent changes in state laws regarding access to health care for young children. Then another programme organizer presented statistical information on how immigrant students, and in particular Somalis, were performing in high school and their challenges in pursuing higher education. Next was a presentation by the 
mosque imam on marital relations and the challenges of conflating Somali cultural norms with Islamic teachings, leading to hierarchical and male-dominated marriage relationships that are detrimental to the wellbeing of the family. Finally, there was a general discussion and participants were asked to reflect on the issues, share their personal experiences, and identify specific challenges to tackle and propose solutions.

The seminar described above reflects the programme's holistic multidimensional approach towards family wellbeing. Each seminar consists of several components that focus on the material, relational, and ethical needs and aspirations of couples and parents, and which are also linked to their place and experiences in the larger society. This holistic approach towards family wellbeing has an affinity with White's argument that wellbeing goes beyond meeting needs or overcoming problems to the pursuit of a meaningful and fulfilling life. Similarly, the programme's vision also highlights an endeavour to promote a well-rounded, fulfilling, and meaningful life. One of the key organizers explains its holistic vision as follows:

We adopt the approach of shumūtiya [Arabic for holistic and comprehensive], we do not focus on only one part of Islam, we have to cover more than one aspect, for example, we have problems with youth, we have problems with our relationships with government, we have to work with other organizations, how to deal with media, with academia. Our approach is broad. (My emphasis)

The use of the term shumūliya by the interlocutor in the quotation above is meant to denote an Islamic reformist approach which emphasizes that seeking and enacting Muslim piety is not confined to religious rituals but has to permeate all aspects of one's life including social relations and interactions in the larger society. The interlocutor explains further that the role of the programme goes beyond ' $d a$ ' $w a$ ' (promoting the faith and teaching its tenants and rituals). It involves tackling in his words "integration, education, health, civilization". He also sees their holistic approach as setting them apart from other mosques in the city since the latter, according to him, do not have the same level of systematic, regular, and goal-focused support for families as the researched mosque does.

In short, the programme organizers see the wellbeing of Somali Muslim families as being multidimensional (material, relational, and ethical) and its realization as taking place through an organic link between one's private family life and membership and active participation in the larger society. Moreover, these religious actors see their institution as playing a crucial role in the pursuit of this goal. 


\section{The al-Usra programme: local and transnational}

\section{Local challenges}

Al-Usra, on one level, is shaped by its local context. It is driven by the challenges facing Muslim minorities in Finland, and more specifically the problems confronted by Somali families. Research shows that Muslim immigrants face a number of socioeconomic challenges such as unemployment, limited possibilities for higher education, and racism (EU-MIDIS, 2009; Kilpi, 2010; Shayan, 2013). In particular, the scholarship on Somalis reports that they face a host of problems such as low educational attainment (especially higher education), high unemployment rate, increasing number of female-headed families, and considerable discrimination and racism (OSF, 2013). The state's welfare policies and discourse emphasizing gender equality and women's autonomy have also added to the marginalization of men, who are often unemployed or underemployed (Peltola, 2016).

These problems, according to many in the Somali communities, have had an adverse impact on family relations. In this diasporic context, women may not need a male provider due to their either receiving welfare provisions or earning their own income, particularly among the younger generation who are reported to do better (than the men) in school and to have job opportunities, particularly in the health sector. Instead, it is the sharing of childcare and housework that becomes needed and more meaningful in marriage (Al-Sharmani, 2015). Lacking the support of the extended family which they had in the home country, women have to shoulder childcare work, especially in a context where their children's wellbeing becomes complex and entangled with state policies and discourses on child welfare on the one hand, and marginalization and racialization of immigrant (Muslim) families on the other (Pösö, 2015). Fathers often do not help with care work either because they are physically away on prolonged transnational trips or divorced from the mothers or are present but feel disempowered and marginalized both by their limited economic opportunities and by the state public policy and discourse on gender equality (see Ismail, this volume). These challenges, in addition to the pressures arising from couples' obligations towards their transnational families, contribute to marital disputes (AlSharmani, 2017; Al-Sharmani and Ismail, 2017). Furthermore, women, becoming more religiously knowledgeable about their marital rights as well as espousing modern ideas about companionate marriages, are increasingly resisting patriarchal marriages (Al-Sharmani, 2015; Al-Sharmani, 2017). Mosque imams witness these problems first hand through their work as mediators and arbiters in family disputes (Al-Sharmani, Mustasaari and Ismail, 2017). It is within this context that programme organizers see their mosque as having a significant role to play in helping families tackle these problems and attain a well-rounded, thriving life by 
promoting a pious, modern, and harmonious Muslim family life where spouses share companionate marriages and partake together in engaged parenting.

The mosque programme's vision is also shaped by Finnish state policies on the governance of religious communities and its discourse on the shared responsibility of state and non-state institutions towards family welfare. Tuomas Martikainen (2014) highlights that, with the 1990s, Finland witnessed socio-political and economic changes, the most notable of which are: increase in the volume of immigration, economic recession, adoption of neoliberal policies that promote efficient public management through privatization of social welfare work and project-based governance, as well as the country's new commitments to EU and global treaties which privilege such policies. Martikainen notes that these changes have led to what he calls a 'desecularization' of Finland, i.e., shifts in the nature of the traditional role of the Finnish welfare state as the sole caretaker and the new expectation that different actors in civil society - such as immigrant associations and religious communities - also share the work of providing "services and goods", and creating "social cohesion" (Martikainen, 2014, p.85). In the case of Muslims, this means the state's relationship with religious communities has changed from a "neutral and marginal" to "an active one" (Martikainen 2014, p.98). For instance, the registration of Muslim religious communities (as well as immigrant associations) has increased significantly since the 1990s. The new visibility of Muslim associations and religious communities has also been enhanced by the establishment of broader organizations concerned with the rights of minorities such as the Ombudsman Office for Minorities in 2002, and the national and regional board for ethnic minorities (ETNO). More specifically the Islamic Council of Finland was also founded, an umbrella organization bringing together different Muslim religious communities.

In the aftermath of $9 / 11$ and with the increasingly hegemonic discourse of the 'war on terror' a global environment of Islamophobia and pathologization of Muslims became ever more visible (Morgan and Poynting, 2012). Notwithstanding these challenges (and partly because of them) the role of mosques in the governance of Finnish Muslims continues to be emphasized in the statist discourse (Martikainen, 2014, p.96).

Programme organizers explicitly frame their work and goals within this state discourse. This is reflected in the organizers' coupling of the good of the family and its positive integration. It is also manifested in how they incorporate into their seminars knowledge about different relevant state and non-state institutions and policies, and encourage participants to interact with these different actors. However, these interlocutors also emphasize that their goal, as an Islamic institution, is to promote a distinct form of integration for Muslim families, one that is underpinned by Islamic values and norms.

The mosque, furthermore, makes use of the legal space created by policies regulating the role and work of religious communities. The programme draws on state resources and agencies - albeit severely insufficient - to conduct some 
of its work. For example, some of the programme's work has been funded by the small annual membership grant that the mosque receives from the state although this grant is primarily intended for the mosque and the associations comprising the mosque's umbrella organization (such as al-Usra) are expected to raise their own funds. Furthermore, in 2016, al-Usra secured professional grants from Helsinki municipality to enrol three of its organizers at the Open University, to study social psychology and organizational management. The interlocutors who took these courses drew on their acquired knowledge in programme seminars and workshops. Still the support that the programme receives from the state (whether financial, professional development, or mechanisms for coordination) remains highly inadequate. Also, organizers undertake the time-consuming work of the programme on a voluntary basis. These challenges, which are encountered by other mosques as well, greatly limit the scope of the mosque programme and its reach (Al-Sharmani, Mustasaari and Ismail, 2017).

\section{The transnational context}

The programme's vision and approach also speak to a larger transnational context. For one thing, the idea of the programme was born in 2009 when the Brussels-based Federation of Islamic Organizations in Europe (FIOE) held a conference in Belgium on the theme of Muslim marital life. FIOE, a Muslim Brotherhood inspired umbrella organization, was founded in 1989 and has hundreds of member organizations across 28 European states. FIOE lists on its website 12 objectives for its mission, the first being, "introducing Islam and its values and shaping Islamic culture in accordance with the requirements of the age and the unique features of the current status of Europe" (FIOE, 2018).

The main purpose of the FIOE 2009 conference, which was attended by one of the key interlocutors in this research, was to promote initiatives that strengthen Muslim marriages and contribute to the stability and wellbeing of Muslim families. The conference proposed a campaign of 100 goals and called on participating organizations to adopt some of these goals. This interlocutor and others in the mosque, in fact, have been part of a loose network of religious scholars and institutions such as FIOE that have been meeting at various Islamic conferences since 2000 and organizing semi-regularly towards the collective goal of educating Muslim families in their respective societies on how to live a modern life that embodies Islamic norms and values while also facilitating their successful integration. In addition to FIOE, diverse Islamic organizations in Europe (including Nordic countries) have also espoused similar Islamic discourse (Maréchal, 2008). Notably, this vision of promoting a modern, tolerant, and pious Muslim way of life is taking place in a context where many diverse Muslim immigrant communities in Europe are facing challenges of multiple forms of marginalization, racialization, and increasing Islamophobia, all of which are also exacerbated by the 
radicalization of some Muslims and the terrorist acts committed by some militant armed Muslim groups both within Western countries and in the Middle East and Africa.

It is in this transnational context that the key interlocutor in the researched mosque, after returning from the 2009 FIOE conference, together with others in the mosque, decided to establish the mosque programme for Muslim families to address the specific challenges of Somali Muslim families in Finland and link it to this larger transnational endeavour to reform European Muslim families. This interplay between the transnational and local is observable in the language used by programme organizers to describe their approach as well as the transnational actors with whom they collaborate. For example, programme organizers, drawing on FIOE language, repeatedly emphasize wastīya (moderation) as their key approach in understanding and promoting the role of Islamic teachings in the lives of Muslim families. Similarly, in the programme's 2015 conference titled 'This is Our Islam', the centrality of moderation as an Islamic value drawn from the Qur'an and the Prophetic tradition was stressed by the key speakers. One of these speakers was Khaled Hanafi, an Egyptian religious scholar and member of the FIOE affiliated organization, the European Council for Fatwa and Research (ECFR). Hanafi argued that European Muslims' enactment of the Islamic value of moderation entailed embracing the culture of citizenship and setting roots in their settled countries. Furthermore, he added, embodying the Islamic virtue of wastìya also meant living gender relations free from male dominance and discrimination against women. This leads me to the question of gender in the work of the mosque programme, which I address in the next subsection.

\section{Reforming gender roles}

\section{Companionate marriages and engaged parenting: an Islamic discourse}

In the vision of the programme, a good family life requires companionate marriages based on affectionate and cooperative spousal relations as well as involved and informed parenting. Both can be attained by acquiring good knowledge of religious norms on marriage and parenting and applying this knowledge to one's family life. This process also entails reflecting critically on Somali cultural norms, some of which privilege male dominance and gendered spousal and parental roles, to the detriment of women who shoulder all care work and children who may not receive the kind of parental care that they need, particularly from their fathers. Somali marriage customs, the speakers in the seminars would frequently argue, discourage couples from expressing affection to each other and fathers from getting involved in childcare. But Islamic marriage is based on mawada and rahma (affection and compassion) as instructed by the Qur'an and attested by the example of the Prophet Muhammad and his followers. ${ }^{5}$ In a 2015 seminar, for instance, the 
mosque imam told the audience about the example of 'Abdullah ibn 'Abbas, the Prophet's companion and an erudite religious scholar, who would dress up nicely for his wife, as an expression of his affection for her. The speaker contrasted ibn 'Abbas' example to that of Somali men who find it unbecoming to express their affection to their wives. In another seminar, the speaker, a Somali religious preacher and motivational speaker from the UK, talked about love as a core Islamic value. The speaker noted that love was mentioned 70 times in the sacred text, an indication of its centrality in the Qur'anic norms. He encouraged participants to be affectionate spouses who communicate with one another, spend time together, and share housework and childcare.

The companionate Islamic marriage being promoted by the programme is also one where spouses cooperatively and flexibly negotiate their spousal and parental roles in light of their lived realities. For instance, in one of the seminars the mosque imam criticized men's understanding of qiwämah - a principle in Islamic jurisprudence that obligates husbands to provide for and protect their wives. The imam pointed out that husbands often erroneously understood and practised qiwāmah as a male prerogative and authority, rather than a responsibility. These problematized religious understandings were attributed to uncritical espousal of Somali cultural norms, which were seen as incongruent with the spirit of Islam and particularly harmful to family wellbeing in the context of migration.

Lena Larson (2015) has similarly written about how the shifting realities of Muslim minority communities in Europe impact religious discourse on gender roles and rights, as constructed by religious actors such as the renowned mufti the late Syed Mutawalli ad-Darsh in the UK and established transnational Islamic institutions such as the European Council for Fatwa and Research (ECFR). Larson shows how these muftis, in light of the new realities of Muslim families in Europe, similar to the religious actors in this researched mosque, have been navigating the process of arriving at nuanced understandings of qiwämah and spousal roles, which foreground husbands' roles as caretakers and involved parents rather than their role as providers.

According to programme organizers, involved and informed parenting is another key component of good Muslim family life. Participants are frequently asked to reflect on why they are having children. Parents are told that children need not only material things such as a good school, adequate housing, clothes, and food, but also nurturing and supportive relationships with their parents. Parents are trained in how to spend quality time with their children, communicate positively with them, guide them towards productive and fulfilling leisure time activities, etc. Again, participants are taught to separate what is 'cultural' from what is 'Islamic' as they relearn how to parent their children. For example, the mosque imam would often note that in Somalia childcare was primarily the role of mothers, whereas fathers were only expected to provide. But he would add that in the diaspora it is not only the changing realities of Somali families that demand revisiting these parental 


\section{2}

Al-Sharmani

roles but also the goal of relearning Islam and living a pious Muslim family life.

In promoting a new Islamic discourse on marriage and parenting, the programme organizers use a mode of argument that posits 'harmful' Somali cultural norms and 'religiously uninformed' family practices of older generations against the 'new piety' being promoted and which emphasizes pursuit of reflective religious learning and embodied Islamic virtues. Similar modes of argument (with their complex and mixed implications for the notion of a gendered Muslim self) have also been reported in scholarship on piety and generational differences among various Muslim immigrant groups in Europe (Amir-Moazami and Salvatore, 2003; Jouili, 2011; Jacobsen, 2011). These modes of argument seem to invoke the language of oppositional binaries (culture versus religion, past versus modern). They also seem to invoke modern registers of individual reasoning and autonomy, and the pursuit of a fulfilling life. Nonetheless, it is misleading to understand the programme's new discourse merely or primarily through the lens of a liberal modernist framework. That is, the underpinning goals of this discourse, while concerned with reform of gender relations, are neither about gender equality nor the attainment of an assimilationist modern life where Islamic norms have little or no presence in participants' lives. In the following subsection, I elaborate on this point through an analysis of the programme's discourse on marriage in relation to modern professional counselling.

\section{Professional marriage counselling and gender reform?}

The programme's discourse on marriage invokes the language of modern professional marriage counselling. Marriage is depicted as 'work' to be undertaken by the spouses to create marital harmony and happiness (Celello, 2009; Davis, 2010). A big part of this work is psychological: organizers, like professional marriage counsellors, advise spouses to know themselves, to choose their marriage partners wisely. Do they have similar interests (e.g., in religion, volunteer work, educational and career goals)? Do they agree on how to manage their resources and navigate their responsibilities towards their transnational relatives? Participants are advised to depart from the old ways in Somalia where, as one organizer put it, "people did not think much about why they were getting married, they just got married." Instead they are to think rationally as they do the 'work' of finding a suitable spouse and creating happy marriages. Kristen Celello (2009) notes how the modernist language and ideology of creating happy marriages has become, in the context of post-World War II America, part of the governance of families towards the goal of a stable thriving nation. In this mosque programme, the reform of marriages is also linked to the goal of the thriving of the Somali Muslim community in the larger Finnish society. But the work of reforming marriages, in this case, is also part of the spiritual striving of individual participants towards the goal of a closer relationship with their divine creator. In 
other words, this work, as one of the mosque imams tells participants, is seen to be as much about participants' 'afterworld', as it is about their 'happiness in this world'.

Also writing about the American context, Rebecca Davis (2010) notes the importance of religious actors in the work of marriage counselling. She highlights how these actors have begun to draw on the field of psychology as they work with their congregations on marriage counselling, driven by the goals of staying relevant in work with families, and by the fact that some of these religious actors have themselves espoused these new ideas and language. In the context of the mosque programme, religious language is also continually mixed with gendered ideas and concepts from modern popular psychology. For instance, participants are told to be cognizant of the different ways in which men and women are socialized and which impact their expectations and behaviour towards their spouses. Husbands are encouraged to listen to their wives, ask them about their day, give them foot massages, compliment them, and show them affection, etc. And wives are encouraged to understand the distinct ways in which men may express their love, not to bombard them with demands and complaints, communicate their needs in a positive blamefree manner, and praise their husbands when the latter do pleasing things, etc.

But does the mosque's work address the question of gender equality? Both Celello and Davis argue that modern marriage counselling has not necessarily created space for gender equality. In some ways it may have even reproduced hierarchical gender norms, as women are frequently socialized to work hard at saving their marriages. In this mosque programme, the revisiting of spousal and parental roles is not based on an agenda of realizing the goal of gender equality. For instance, some of the unequal spousal and parental rights in Islamic jurisprudence are not questioned. Men, not women, are still believed to have the religious duty to provide for their families. Unlike women, men have the right to unilateral repudiation, and can enter into polygamous marriages. But through its activities, the programme is increasingly foregrounding an ethically oriented reading of Islamic law which is based on the lived realities of participants. This interestingly leads to revisiting these male privileges. Thus, programme organizers admonish belligerent men who refuse to divorce their wives when the latter want to exit the marriages, depicting the behaviour of such men as un-Islamic. They also advise against the practices of men who enter into polygamous marriages to the detriment of their wives and children. This ethical reading of Islamic law and the centring of families' lived realities results in men becoming the focus of this reform work. That is, traditional Somali understandings of privileged masculinity and male rights are revisited and problematized as part of a larger effort to promote a new Islamic viewpoint of gender roles in marriage and parenting.

Still, the lack of explicit and coherent commitment to gender equality as a programme goal is reflected in the contestations that take place at some of the events. For example, in the 2015 conference, a female participant asked one of the speakers about the right of women to insert stipulations in their marriage 


\section{4}

Al-Sharmani

contracts against polygamy. The answer of this speaker, a well-known Somali religious scholar who is based in the UK, was that while couples could agree on stipulations in the marriage contract, polygamy was permissible in Islam. This scholar, in other words, was reluctant to categorically endorse the practice of writing stipulations against polygamy, as it contradicted his understanding of polygamy as a male prerogative sanctioned by the sacred text. Yet, in another seminar, one of the mosque imams while not explicitly encouraging the use of stipulations against polygamy talked about the importance of following the Prophet's example in spousal relations and pointed out that men often - because of either poor religious knowledge or lack of piety - erroneously justified their practice of polygamy on religious grounds, while failing to emulate the Prophet in his affectionate and respectful relationships with his spouses. These varying positions towards restricting men's right to polygamy are to be juxtaposed with the mosque's strong encouragement of women and men to become more knowledgeable about their religious tradition and to use this knowledge to reform their marriages. This has subsequently led to more women seeking religious education, and as a result in recent years there began an increasing trend of women (particularly the younger generation) inserting stipulations in their marriage contracts against polygamy, and some of these women were even formulating very nuanced religious arguments that made it spiritually imperative for them to reject polygamy (Al-Sharmani, 2015).

Additionally, pathways of empowerment for some women have been enabled through their involvement in the mosque and participation in the programme activities. Some women who help with the programme work, for example, have been able to lobby for the inclusion of their concerns in the activities. In one case, two members of the women's association in the mosque proposed 'love in Islam' as the theme of one of the seminars and invited two speakers from the UK, a mosque imam and his wife, both of whom are wellknown Islamic motivational speakers in the Somali diaspora. Also, with the help of the network of people established through the programme and the knowledge gained from its activities, one of the female participants has been able to seek opportunities for higher education and employment. Furthermore, she established, with another friend, a small women's association in her neighbourhood, where they hold family seminars and after-school activities for children in coordination with the mosque.

\section{Conclusion}

This case study shows the significance of wellbeing as a conceptual tool to understand the multi-layered needs, challenges, and aspirations of Finnish Somali families from the perspective of a religious institution. The mosque programme makes the case that the pursuit of an all-round meaningful life requires a holistic processual reform that attends to different dimensions of participants' family lives and links this reform to the attainment of 
empowered membership in the larger society. It shows how religion and involvement in mosque activities can be a pathway towards the pursued transformative change. Furthermore, by promoting an Islamically oriented family wellbeing and integration, the mosque is exhibiting its agency vis-à-vis the state as a significant actor in the governance of Muslim Finnish citizens, and which entails both working for their welfare and partaking in their identity building.

However, the mosque programme's efforts are focused on spouses, parents, and youth. Its underlying message seems to be that individual family members can and should be the main agents of change through a multidimensional self-reform process that combines acquisition of multidimensional knowledge and embodiment of Islamic virtues in the family and larger society. Does this focus on individual family members conceal the role of state institutions as well as ethnic and religious communities in enabling or hindering the pursued positive change? One could argue that the mosque's programme is inadvertently concealing the structural problems that preclude the wellbeing and integration of Finnish Somali Muslim families, i.e., economic, social, and racial barriers to their full participation in different domains of Finnish society. White (2016) cautions against such an understanding of wellbeing, which may focus too much on the individual and not enough on the role of institutional actors and structural factors. But one could also counter-argue that the programme, with its efforts to contest hierarchical and gendered spousal and parental roles and its sought goal of empowering Muslim families in the larger society, can be said to have elements that could potentially facilitate the needed structural changes.

Still, to what extent is the programme reforming hierarchical gender norms and relations in Muslim Somali families? This needs further research. The programme activities target women, men, and youth. It is predominantly women who attend and take part in the activities, while men's (especially married men's and fathers') attendance is still not large. This, on the one hand, limits the impact of this programme on changing men's behaviour. On the other hand, both young men and women actively participate in the youth seminars and this could, in the long run, be one mechanism through which change is affected in gender relations.

Lastly, while other mosques also work with families, what is distinct about this mosque programme is its systematic and coherent vision. It is also noteworthy that its work is enabled by a number of factors: the organizers' espousal of a distinct Islamic discourse on how Muslims can lead a pious and fulfilling life in Finland and more broadly in Europe; their ties with diverse networks of individual and institutional religious actors on the continent who are undertaking crisscrossing reform efforts; the long-term involvement of young women and men in the mosque's reform efforts. Still further longitudinal research is needed on this programme, and possible motivations and avenues for collaboration between the various mosques in the country to 
pursue broader organized efforts for the wellbeing of Muslim families of different ethnicities.

\section{Notes}

1 This chapter is part of a study titled Transnational Somali Muslim Families in Finland: The Lived Realities and Discourses of Marriage designed and directed by the author. It is part of a larger Academy of Finland research project titled Transnational Muslim Marriages: Wellbeing, Law, and Gender (2013-2018).

2 I extend my thanks to all the interlocutors who graciously and generously took part in this study.

3 With the exception of the oldest mosque, built by the Tatar community, all other mosques are housed in buildings that are intended for other use.

4 Mosques need to be licensed by the registrar office to conclude legally recognized and registered marriages. Most mosques that conclude marriages are licensed. The divorces concluded by mosques are strictly religious and are not recognized by the state. See Al-Sharmani, Mustasaari and Ismail (2017).

5 Qur'an 30:21.

\section{Bibliography}

Abu-Lughod, L., 1990. Can there be a feminist ethnography? Women and Performance: A Journal of Feminist Theory, 5(1), pp.7-27.

Al-Sharmani, M., 2015. Striving against the 'Nafs': Revisiting Somali Muslim spousal roles and rights in Finland. Journal of Religion in Europe, 8(1), pp.101-120.

Al-Sharmani, M., 2017. Divorce among transnational Finnish Somalis: Gender, religion, and agency. Religion and Gender, 7(1), pp.70-87.

Al-Sharmani, M. and Ismail, A.A., 2017. Marriage and transnational family life among Somali migrants in Finland. Migration Letters, 14(1), pp.38-49.

Al-Sharmani, M., Mustasaari, S. and Ismail, A.A., 2017. Faith-based family dispute resolution in Finnish mosques: Unfolding roles and evolving practices. In: S. Bano, ed. 2017. Gender and Justice in Family Law Disputes: Women, Mediation and Religious Arbitration. Waltham, MA: Brandeis University Press, pp.270-291.

Amir-Moazami, S. and Salvatore, A., 2003. Gender, generation, and the reform of tradition: From Muslim majority societies to Western Europe. In: S. Allievi and J. Nielsen, eds. 2003. Muslim Networks and Transnational Communities in and Across Europe. Boston and Leiden: Brill, pp.52-77.

Celello, K., 2009. Making Marriage Work: A History of Marriage and Divorce in the Twentieth Century United States. Chapel Hill, NC: University of North Carolina Press.

Davis, R.L., 2010. More Perfect Unions: The American Search for Marital Bliss. Cambridge, MA: Harvard University Press.

EU-MIDIS, 2009. European Union Minorities and Discrimination Survey: Main Results Report. Vienna: European Union Agency for Fundamental Rights. Available at: http://fra.europa.eu/sites/default/files/fra_uploads/663-fra-2011_eu_midis_en. pdf [Accessed January 12, 2018].

Federation of Islamic Organizations in Europe (FIOE), 2018. Objectives. Available at: http://fioe.org/node/173 [Accessed July 28, 2018].

Jacobsen, C., 2011. Troublesome threesome: Feminism, anthropology, and Muslim women's piety. Feminist Review, 98, pp.65-82. 
Jouili, J., 2011. Beyond emancipation: Subjectivities and ethics among women in Europe's Islamic revival communities. Feminist Review, 98, pp.47-64.

Kääriäinen, K., 2011. Religion and state in Finland. Nordic Journal of Religion and Society, 24(2), pp.155-171.

Ketola, K., Martikainen, T. and Salomäki, H., 2014. New communities of worship: Continuities and mutations among religious organizations in Finland. Social Compass 61(2), pp.153-171.

Kilpi, E., 2010. The Education of Children of Immigrants in Finland. PhD. University of Oxford. Available at: http://citeseerx.ist.psu.edu/viewdoc/download?doi=10.1.1. 696.1088\&rep $=$ rep1\&type $=$ pdf [Accessed January 10, 2018].

Larson, L., 2015. 'Men are the protectors and maintainers of women...' Three fatwas on spousal roles and rights. In: Z. Mir-Hosseini, M. Al-Sharmani and J. Rumminger, eds. 2015. Men in Charge? Rethinking Authority in Muslim Legal Tradition. Oxford: OneWorld, pp.197-218.

Maréchal, B., 2008. The Muslim Brothers in Europe: Roots and Discourse. Leiden: Brill.

Martikainen, T., 2014. Muslim immigrants, public religion, and developments towards a post-secular Finnish welfare state. Tidsskrift for Islamforskning, The Nordic Welfare State, 8(1), pp.78-105.

Morgan, G. and Poynting, S., eds. 2012. Global Islamophobia: Muslims and the Moral Panic in the West. Farnham: Ashgate.

Mårtensson, U., 2014. Introduction - 'public Islam' and the Nordic welfare state: Changing realities? Tidsskrift for Islamforskning, The Nordic Welfare State, 8(1), pp.4-55.

OSF, 2013. Somalis in Helsinki. New York and London: Open Society Foundations. Available at: https://www.opensocietyfoundations.org/sites/default/files/somalis-hel sinki-20131121.pdf [Accessed January 2, 2018].

Peltola, M., 2016. Respectable families: Discourses on family life, ethnic hierarchies and social positioning. Ethnicities, 16(1), pp.22-39.

Pösö, T., 2015. How the Finnish child protection system meets the needs of migrant families and children. In: M. Skivenes, R. Barn, K. Kriz and T. Pösö, eds. 2015. Child Welfare Systems and Migrant Children: A Cross Country Study of Policies and Practices. Oxford: Oxford University Press, pp.19-38.

Sakaranaho, T., 2013. Religious education in Finland. Temenos, 49(2), pp.225-254.

Shayan, F., 2013. Ontological anxiety among Shii Muslims in Finland: A case study of first generation immigrants in the city of Tampere. Islamic Perspective: Journal of the Islamic Studies and Humanities, 9, pp.91-106.

Statistics Finland, 2016. Population structure. Language according to age and sex by region in 1990 to 2016. Available at: http://pxnet2.stat.fi/PXWeb/pxweb/en/StatFin/ StatFin_vrm_vaerak/statfin_vaerak_pxt_010.px/?rxid=40252902-b370-44ea -8183-d2fc305596e6 [Accessed January 2, 2018].

White, S.C., 2008. But What is Wellbeing? A Framework for Analysis in Social and Development Policy and Practice. Paper for Regeneration and Wellbeing: Research into Practice, University of Bradford, 24-25 April 2008. University of Bath, Centre for Development Studies. Available at: http://staff.bath.ac.uk/ecsscw/But_what_is_ Wellbeing.pdf [Accessed January 2, 2018].

White, S.C., 2010. Analysing wellbeing: A framework for development practice. Development in Practice 20(2), pp.158-172.

White, S.C., 2016. The many faces of wellbeing. In: S.C. White and C. Blackmore, eds. 2016. Cultures of Wellbeing: Method, Place, and Policy. Basingstoke: Palgrave Macmillan, pp.1-46. 